\section{SKELETAL DEFORMITIES IN A FEW FRESHWATER FISHES FROM BHAVANI RIVER, TAMIL NADU}

\section{A. Jesu Arockia Raj, S. Seetharaman and M.A. Haniffa}

Centre for Aquaculture Research and Extension (CARE), St. Xavier's College (Autonomous), Palayamkottai, Tamil Nadu 627002, India.

web supplement

Deformities in teleosts are occasionally found in natural and/ or wild population. Such phenomenon is quite common among the animals kept in zoos for captive propagation (Sennar, 1980; Tutman et al., 2000). Several studies have focused on the deformities of the skeletal region, and a wide range of causes has been noticed, including genetic variance (hereditary factors), inbreeding depression, significant ecosystem changes viz., temperature, $\mathrm{pH}$, parasitism, nutritional deficiencies and environmental contamination (from pollutants) (Orska, 1962; Koumoun-douros et al., 1997). Numerous reports are available regarding the present study in other species viz., Cirrhinus mrigala and Hypothalmichthys molitrix (Panday \& Awasthi, 1994) probably due to inbreeding depression. Similar abnormal features have also been observed among a few endangered fish species, namely, Salmo trutta (Poynton, 1987), Micropterus dolomieni (Avyle et. al., 1989) and Oncorhynchus mykiss (Madsean \& Dalsgard, 1999). The present study reports the skeletal deformities found in wild populations of a few freshwater catfishes Mystus cavasius, Ompok bimaculatus and Heteropneustes fossilis, murrel Channa striatus and $C$. puntatus and featherback Notopterus notopterus.

Between December 2002 and March 2003, fishes were collected from river Bhavani (Bhavanisagar Dam, Erode Dist., Tamil Nadu, India) [as a part of the study of the endangered freshwater fish species for its conservation by induced breeding techniques in captivity] using cast net between 0500 and $0600 \mathrm{hr}$ and between 1700 and $1800 \mathrm{hr}$. They were transported to the Centre for Aqaculture Research and Extension (CARE) and stocked in a 5000lt fibre tank. Before the introduction of these species into culture pond, their length and weight were recorded. At the time some of the deformed individuals were noticed occasionally and kept separately. Among the 227 individuals (M. cavasius - 59, O. malabaricus - 78, Heteropreustes fossilis - 20, C. striatus - 12, C. punctatus - 28, and N. notopterus - 30) totally eight were deformed, viz., M. cavasius - 1 (Image $1^{\mathrm{w}}$ ), $O$. bimaculatus - 1 (Image 2w), Heteropreustes fossilis - 1, C. striatus - 1 (Plate 3), C. punctatus - 3 (Images 4-6w), and N. notopterus 1) and the percentage of deformity was calculated. The skeletal deformed individuals of $M$. oculatus, O. bimaculatus, and Heteropreustes fossilis were examined by radiography using a medical x-ray system (Plate 7a-7c). The deformed fishes were shorter than normal, had curved spinal chord either in vertical or horizontal region but other internal organs were normally developed. The deformity was noticed in the dorsal region $(C$. striatus) and the caudal peduncle region was slightly curved upward and downward in C. striatus (Image $3^{\mathrm{w}}$ ), M. cavasius and $O$. bimaculatus and the other two C. punctatus (Images $5^{\mathrm{w}}$ $\& 6^{\mathrm{w}}$ ) were deformed in caudal fin region being bent sideways. Literature shows that abnormalities of the vertebral column are relatively frequent and variable in prevalence and is always higher in the wild than in captivity (Table 1).

Similar reports are available on the prevalence of spinal deformities e.g., Fundulus heteroclitus (Gabriel, 1944) and Esox lucicus (Orska, 1962). Unfavorable environmental factors as well as various degrees of inbreeding have also been attributed to malformation of the vertebral column among cultivated fish species. Skeletal deformities can be environmentally induced in two ways (i) by alteration of biological processes necessary for maintaining the biochemical integrity of bone or (ii) neuromuscular effects, which lead to deformities without chemical change in vertebral composition. Numerous pesticides including organo-chlorines, polychlorinated biphynels and fluorinated herbicides can cause skeletal deformities of various fish species in natural and reared conditions (Wiegand et al., 1989; Chattain, 1994). These compounds typically cause fractures, many organic contaminations alter bone metabolism and affect biochemical composition of vertebral column (Mayer et al., 1975) but this was not detected in our study. Acid precipitation has also been suggested as a potential cause of skeletal deformities in fishes (Sarkar \& Kapoor, 1956; Andrades et al., 1996). Metals such as cadmium, zinc, mercury and lead cause skeletal deformities in fish by altering bone metabolism and can also affect the neuromuscular system (Sauer \& Watanabe, 1984; Davies et al., 1976)

In our study, the deformities seem to have multifactorial (environmental contamination, genetic factors and inbreeding depression) explanations. Conclusively, we were unable to determine the exact source of the deformities. But the several evaluation reports indicate that the detection of such abnormalities can be preferred at very early developmental stage

Table 1. Number of vertebral column (normal and deformed), region of skeletal deformation and percentage of deformity in the freshwater fish species

\begin{tabular}{|c|c|c|c|c|}
\hline \multirow[t]{2}{*}{ Species } & \multicolumn{2}{|c|}{ Number of vertebral column } & \multirow[t]{2}{*}{ Region of skeletal deformation } & \multirow[t]{2}{*}{ Percentage of deformity } \\
\hline & Normal & Deformed & & \\
\hline Ompok bimaculatus & 53 & 47 & Caudal peduncle & 1.28 \\
\hline Mystus cavasius & 43 & 36 & Caudal peduncle & 1.69 \\
\hline Channa punctatus I (Image 4) & 38 & 34 & Caudal peduncle & 10.70 \\
\hline Channa punctatus II (Image 5) & - & - & Caudal fin (Normal-18 fin rays; Deformed-15 fin rays) & 10.70 \\
\hline Channa punctatus III (Image 6) & & - & Caudal fin (Normal-18 fin rays; Deformed-12 fin rays) & 10.70 \\
\hline Channa striatus & $\overline{5} 7$ & $\overline{5} 1$ & Dorsal region & 8.33 \\
\hline Heteropneustes fossilis & 61 & 54 & Caudal peduncle & 3.84 \\
\hline Notopterus notopterus & 69 & 61 & Dorsal region & 3.33 \\
\hline
\end{tabular}

Manuscript 1145; Received 5 February 2004; Revised received 31 May 2004; Finally accepted 10 July 2004; @ Zoo Outreach Organisation; www.zoosprint.org 
and also expression of some homoeotic genes in the skeletal region, for example, in zebra fish Brachydanio nerio (Joly et $a l .$, 1993). For this reason further detailed research of this phenomenon will concentrate the mechanism of spinal deformation during early embryogenesis.

\section{REFERENCES}

Andrades, J.A., J. Berrara and P. Fernandez-llebrez (1996). Skeletal deformities in larval, juvenile and adult stages of cultured gilthead sea bream (Sparus aurata). Aquaculture 141: 1-11.

Avyle, V.D.M.J., S.J. Carvick, V.S. Blazer, S.J. Hamilton and W.G. Brumbaugh (1989). Skeletal deformities in Small Mouth Bass, Micropterus dolomieni from southern Appalachian Reservoirs. Archives of Environmntal Contanmination and Toxicolology 18: 688-696.

Chattain, B. (1994). Abnormal swim bladder development and lordosis in Sea Bass (Dicentrachus labrax) and Sea Bream Sparus auratus. Aquaculture 119: 371-379.

Davies, P.H., J.P. Goettl, J.R. Sinley and N.F. Smith (1976). Acute and chronic toxicity of lead to rainbow trout Salmo gairdneri, in hard and soft water. Water Research 10: 199-206.

Gabriel, M.L. (1944). Factors affecting the number and form of vertebrae in Fundulus heteroclitus. Journal of Experimental Zoology 95: 105-147.

Joly, J., S. Joly, C. Schulte, S. Merker, S. Boule and H. Condamine (1993). The ventral and posterior expression of the Zebra Fish homeobox gene level is protruded in dorsalized and mutant embryos. Development 119: 1261-1275.

Koumoundouros, G., F. Gagliardi, P. Divanach, C. Boglione, S. Cataudella and M. Kentouri (1997). Normal and abnormal osteological development of caudal fin in Sparus aurata L. fry. Aquaculture 149: 215-226.

Mayer, F.L., P.M. Mehrle, R.A. Schoettger (1975). Collagen metabolism in fish exposed to organic chemicals, pp. 31-54. In: Recent Advances in Fish Toxicology: Ecological Research Series. Corvallis, Oregon.

Madsean, L. and I. Dalsgard (1999). Vertebral column deformities in farmed rainbow trout on Oncorhynchus mykiss. Aquaculture 171: 41-48.

Panday, K.D. and S.K. Awasthi (1994). p. 13. In: Dehadari, P.V., P. Das and S.R. Verma (Eds.). Threatened Fishes of India Nature Conservators, Muzaffarnagar, 480pp.

Poynton S.L. (1987). Vertebral column abnormalities in Brown Trout Salmo trutta. Journal of Fish Diseases 10: 53-57.

Orska J. (1962). Anomalies in the vertebral columns of the Pike Esox lucicus. Acta Biological Cracovtenym Series for Zoology 5: 327-345.

Sarkar, H.L. and B.G. Kapoor (1956). Deformities in some catfishes. Journal of Zoological Society of India 8(2): 157-164.

Sauer, G.R., N. Watanabe (1984). Zinc uptake and its effect on calcification in the scales of the Mummichog Fundulus heteroclitus. Aquature Toxicology 5: 51-66.

Sennar, I.W. (1980). An Evolutionary Ecological Perspective, p.161. In: Soule, M.E. and B.A. Wilcox (Eds.). Conservation Biology. California University Press, California.

\section{ACKNOWLedGement}

Thanks are due to Rev. Dr. A. Antonysamy, S.J., Principal, St. Xavier's College, Palayamkottai for providing necessary facilities to carry out this study.

\section{OCCURRENCE OF THE SHORT-NOSED FRUIT BAT (CYNOPTERUS SPHINX VAHL, 1797) IN THE THAR DESERT OF RAJASTHAN}

\section{Sumit Dookia}

Desert Regional Station, Zoological Survey of India, Jhalamand, Jodhpur, Rajasthan 342005, India

Email: sdookia_gazelle@rediffmail.com

The chiropteran fauna of the Rajasthan Thar Desert is mainly known through the works of Prakash (1963), Sinha $(1979,1980)$ and Gaur (1981), where they recorded a total of 24 species (both Megachiroptera and Microchiroptera). Although the Short-nosed Fruit Bat, Cynopterus sphinx, is one of the common chiropteran species in India, it is not commonly encountered in the Indian Thar Desert. In Rajasthan, Advani (1982) reported it from Banswara, Bundi and Jhalawar, whereas, Sinha (1980) reported this species from Banswara and Bundi in a guava orchard. Prater (1971) gives the distribution of this species from peninsular India and Southeast Asia. Prakash (1963) and Bates et al. (1994) did not report this species from Thar Desert of Rajasthan.

On 6 February 2003, in one of our intensive tour program to survey the faunal diversity of the Thar Desert, I visited Bhinmal, a Tehsil of Jalore District, which comes under the semi arid part of Thar Desert tract. There I observed 18 Short-nosed Fruit Bats actively feeding on Zizyphus jujuba trees, with an assemblage of Pteropus giganteus, inside the city at the Government Dak Bungalow Campus. These bats were seen feeding while flying. They picked up ripe berries and sucked the pulp during flight, dropped the seed and returned to the tree for another fruit. The bats repeated this until midnight.

The probable reason for the occurrence of this species in the semiarid region of Thar Desert might be due to several newly established fruit orchards and the introduced date palm trees which provide a natural roost (CAZRI, Jodhpur unpub. data).

\section{REFERENCE}

Advani, R. (1982). Distribution and status of chiroptera species in Rajasthan, India. Saugertierkundliche Mitt. 30(1): 49-52.

Bates, P.J.J., D.L. Harrison and M. Muni (1994). The bats of eastern India, revised - Part I. Journal of the Bombay Natural History Society 91(1): 1-15.

Gaur, B.S. (1981). Ecology of the bats of the Indian Desert. Ph.D. Thesis. University of Jodhpur, Jodhpur, 110pp.

Prakash, I. (1963). Taxonomic and biological observations on the bats of the Rajasthan Desert. Records of Indian Museum 59(1-2): 149-170.

Prater, S.H. (1971). The Book of Indian Animals. $3^{\text {rd }}$ edition. Bombay Natural History Society, Bombay, 324pp.

Sinha, Y.P. (1979). Studies on taxonomy, distribution, zoogeography, osteology and field ecology of bats of Rajasthan, specially the Indian Desert. Ph.D. Dissertation. University of Jodhpur, Jodhpur, 204pp.

Sinha, Y.P. (1980). Further observations on the field ecology of Rajasthan bats. Journal of the Bombay Natural History Society 77(3): 465-470.

\section{ACKNOWLEDGEMENT}

The author is grateful to Dr. Q.H. Baqri, Principal Investigator and Addl. Director, Desert Regional Station, Zoological Survey of India and MoEF, New Delhi for financial assistance and Late Prof. I. Prakash for guiding me time and again about mammalian fauna of this region.

Manuscript 1137; Received 6 January 2004; Finally accepted 1 July 2004; (C) Zoo Outreach Organisation; www.zoosprint.org 